\title{
NA OBRZEŻACH Literatury \\ Portret Andrzeja Rocha Świętochowskiego - POETY DZIEDZICZONEJ TRAUMY
}

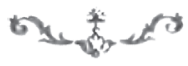

A NDRZEJ Roch ŚwięTochowski znany jest dziś raczej badaczom XIX wieku jako geograf, nauczyciel szkół prywatnych, wieloletni dyrektor Warszawskiego Towarzystwa Ubezpieczeń od Ognia, społecznik. Historia pamięta go też jako współredaktora Słownika Geograficznego, Wielkiej Encyklopedii Ilustrowanej, współautora (obok Wacława Nałkowskiego) Wielkiego Atlasu Geograficznego ${ }^{1}$. Odnotowuje się również jego nazwisko jako autora korespondencji z Warszawy w sprawach społecznych i ekonomicznych, które umieszczał w petersburskim „Kraju” od 1877 roku. Wiadomo, że przez całe swe długie życie wiele podróżował, zwiedził Niemcy, Austrię i Włochy. Wciąż bardziej znany pozostaje zatem historykom kartografii i historykom ubezpieczeń w Polsce niż historykom literatury, czekając na swoje hasło w Polskim Słowniku Biograficznym. W drugiej połowie XX i na początku XXI wieku jego postać przywoływana była dość rzadko i raczej na marginesie rozpraw historycznych. Raz wymieniono go na kartach fundamentalnego Pokolenia Szkoły Głównej Stanisława Fity², cytowany bywa zwykle jako autor wspomnień ze szkoły kieleckiej, te zaś służą jako kontekst dla rekonstrukcji wczesnej fazy biografii Adolfa Dygasińskiego, genezy Syzyfowych prac Stefana Żeromskiego czy studiów nad dziejami Kielc i szkolnictwa w Królestwie Polskim³.

1 O czterdziestoleciu pracy zawodowej i wspomnianych publikacjach Andrzeja Świętochowskiego - zob. „Tygodnik Ilustrowany” 1911, nr 32, s. 633.

2 Zob. S. Fita, Pokolenie Szkoły Głównej, Warszawa 1980, s. 54.

3 Doświadczenia Świętochowskiego z okresu Szkoły Wyższej Realnej w Kielcach sta- 
Andrzej Świętochowski - student Szkoły Głównej, rówieśnik warszawskich pozytywistów - jest również zapomnianym i, jak się zdaje, niedocenionym pisarzem ${ }^{4}$. $Z$ jego spuścizny zostały ostatnio przywrócone historii piśmiennictwa polskiego interesujące pamiętniki ${ }^{5}$. Warta uwagi jest też jednak twórczość poetycka Świętochowskiego, zachowana w rodzinnym rękopiśmiennym archiwum i do tej pory w większości niepublikowana ${ }^{6}$.

Przypomnijmy pokrótce biografię Andrzeja Rocha Świętochowskiego. Tło biograficzne stanowi bowiem pomocniczy kontekst dla zrozumienia jego poezji, a zwłaszcza prezentowanego bliżej w niniejszym artykule Snu więźnia. Andrzej Roch, syn Ignacego, powstańca 1831 roku, urodził się 16 sierpnia 1844

ły się kontekstem dla biografii Dygasińskiego (por. m.in. D. Brzozowska, Adolf Dygasiński, Warszawa 1957, s. 23; M. Radowska-Lisak, „Niedobre wspomnienia wielce drażliwych okoliczności”. Echa Powstania Styczniowego w prozie Adolfa Dygasińskiego, „Niepodległość i Pamięć” 2014, nr 1/2) oraz - poprzez kontrast - do badania kulturowego tła Syzyfowych prac Żeromskiego (por. W. Słodkowski, „Syzyfowe prace” Stefana Żeromskiego, Wrocław-Warszawa-Kraków 1966, s. 296-297; Wokół „Syzyfowych prac". Problemy edukacji wiejskiej w Polsce w XIX i XX wieku, red. M. Pawlina-Meducka, Kielce 1999, s. 63-64). Zob. też: Kielce w pamiętnikach i wspomnieniach $z$ XIX wieku, oprac. i przygotowanie do druku A. Massalski i M. Pawlina-Meducka, Kielce 1992, s. 113.

4 Nazwisko Andrzeja Rocha Świętochowskiego odnotowuje Paweł Hertz. Por. Zbiór poetów polskich XIX w., ułożył i oprac. P. Hertz, ks. 6, Warszawa 1975, s. 981-982.

5 Zob. A.R. Świętochowski, Moje wspomnienia (1844-1871), rękopis przepisała E.B. Sosnowska, oprac. K. Jaworski, wstęp M. Sosnowski i K. Jaworski, Warszawa 2013.

6 Ocalała rękopiśmienna spuścizna poetycka Świętochowskiego zawiera się w dwóch zeszytach przechowywanych w zbiorach rodzinnych Ewy Beaty i Mirosława Sosnowskich. Zeszyt [1] o formacie $200 \mathrm{~mm} \times 160 \mathrm{~mm}$ liczy 50 stron. Brak okładki, uszkodzone szycie, papier gładki, pożółkły, strony nieliczbowane, s. [1-14] - zapisane czarnym atramentem, s. [15-16] - wakaty, s. [17-33] - zapisane czarnym atramentem. Na pierwszej stronie na przekreślonym ołówkiem tekście notatka niebieską kredką: „Z tych moich prób wiele marnych i głupio pomyślanych, niektóre coś warte", tekst na niektórych stronach przekreślony ołówkiem. W zeszycie [1] Świętochowski pomieścił 24 utwory liryczne - powstałe między 1861 a 1864 rokiem (najprawdopodobniej zeszyt pochodzi z tamtego okresu). Zeszyt [2] o formacie $208 \mathrm{~mm}$ $\times 160$ mm liczy 154 strony. Defekt okładki: zachowała się tylna karta, karty papieru zszyte, papier gładki, pożółkły, strony liczbowane i nieliczbowane: s. [1-17] - brudnopisowy zapis poematu dramatycznego Don Karlos. Infant hiszpański, zapis czarnym atramentem, s. 18-10o - czystopis wierszy - czarnym oraz niebieskim atramentem (s. 35, 36, 81 i 87 - wakaty) oraz s. [101-119] - czystopis utworu Stanisław Lach. Obraz dramatyczny. Ostatni zapisany w zeszycie utwór datowany jest na 1920 rok (rękopis powstał zatem między 1920 a 1928 rokiem). 
roku w Sławkowie. Pierwszych pięć lat swego życia spędził w Niesułowicach u dziadków Kluszczyńskich. Do ojca i rodzinnego Sławkowa powrócił w 1850 roku, już po śmierci matki, Emilii z Kluszczyńskich primo voto Nielepiec. Pierwsze nauki pobierał w szkole elementarnej w Niesułowicach, a następnie w Dąbrowie Górniczej, gdzie uczył się tylko rok. Rodziny nie było stać na opłacenie czesnego. Ignacy Świętochowski, którego marzeniem było, aby wszyscy synowie zdobyli chociaż podstawowe wykształcenie, postanowił sam przygotować dwóch synów - starszego Stefana i młodszego Andrzeja (najstarszy Tadeusz legitymował się już wtedy świadectwem ukończenia klasy czwartej) - do egzaminów do klasy drugiej Szkoły Wyższej Realnej w Kielcach. W 1855 roku Andrzej Świętochowski zdał egzamin do klasy drugiej tegoż gimnazjum. Jeszcze raz, z powodu braku pieniędzy na opłacenie czesnego, musiał przerwać naukę i rok szkolny 1856/1857 spędził w rodzinnym domu. Wiedzę objętą programem szkolnym przyswajał samodzielnie. Gimnazjum kieleckie ukończył w 1861 roku z pierwszą nagrodą (obok Bolesława Prusa, Dygasińskiego i Żeromskiego znalazł się później na liście zasłużonych wychowanków tej szkoły) ${ }^{7}$. Dalsze kształcenie syna w ogóle nie było brane przez ojca pod uwagę. W latach 1861-1863 Świętochowski mieszkał u brata Tadeusza w Miechowie i pracował razem z nim, najpierw u inżyniera Jakuba Wysockiego, zawiadowcy dróg bitych południowej części ówczesnej guberni radomskiej, potem zaś u Józefa Chełmińskiego, inżyniera powiatowego. Pomiędzy tymi zatrudnieniami próbował też pracy jako guwerner. To doświadczenie w sposób istotny wpłynęło na jego późniejsze życie. Na ten okres datują się pierwsze utwory poetyckie Świętochowskiego - utrzymane przede wszystkim w konwencji postsentymentalnej i postromantycznej.

Kiedy wybuchło powstanie styczniowe, Świętochowski przebywał w Miechowie i był świadkiem walk powstańców pod wodzą Apolinarego Kurowskiego i krwawego odwetu Rosjan. Wypędzony wraz z innymi mieszkańcami z Miechowa, skorzystał z gościny teścia swojego brata Tadeusza, Michała Katarzyńskiego, ówczesnego wójta gminy Giebułtów i kilka tygodni spędził w Książu Małym. Przeżywszy, dzięki szczęśliwemu zbiegowi okoliczności, napad Rosjan na Giebułtów, udał się do Krakowa. Marzenia o wstąpieniu do oddziałów Mariana Langiewicza runęły w gruzy, bliższe zetknięcie się z niektórymi powstańcami w Krakowie przyniosło gorycz i rozczarowanie. W Krakowie, przez dwa miesiące - kwiecień i maj 1863 roku - pracował jako uczeń

7 Por. Księga pamiątkowa kielczan 1856-1904, wydana zokazji zjazdu wychowańców gimnazjum w Kielcach 7 i 8 września 1924 r., red. T. Ruśkiewicz, Warszawa 1925, s. $210-211$. 
aptekarski w aptece Piotra Krokiewicza, w czerwcu - w biurze Towarzystwa Wzajemnych Ubezpieczeń, w lipcu otrzymał pracę korepetytora i nadzorcy w pensjonacie Dobrzęckiego przy ulicy Jagiellońskiej. Od września 1863 do połowy marca 1864 roku uczęszczał jako wolny słuchacz na wykłady Józefa Majera i Józefa Kremera na Uniwersytecie Jagiellońskim. Pod koniec marca 1863 roku, zgodnie z zaleceniem władz austriackich działających pod wpływem Rosjan, musiał opuścić Kraków i wrócić do Królestwa. Od kwietnia do sierpnia 1863 roku przebywał u brata Tadeusza w Olkuszu, pomagając mu w pracach biurowych i przygotowując do klasy trzeciej gimnazjum dwóch synów miejscowych urzędników. Wolny czas przeznaczał na intensywną lekturę i myślenie o tym, jak spełnić marzenie i wstąpić do utworzonej w 1862 roku Szkoły Głównej Warszawskiej. Przyjaźń z Michałem Katarzyńskim umożliwiła ostatecznie realizację tego celu. Objęty wsparciem finansowym we wrześniu 1864 roku Andrzej Roch Świętochowski przyjechał do Warszawy i w październiku, po zdaniu egzaminów, został studentem pierwszego roku na Wydziale Matematyczno-Fizycznym Szkoły Głównej ${ }^{8}$. W tym roku też powstał wiersz Sen więźnia.

Odnowiona przyjaźń z Adolfem Dygasińskim spowodowała, że pod jej wpływem Świętochowski w 1865 roku zmienił wydział Szkoły Głównej na Filologiczno-Historyczny i ukończył go w 1869 roku. Po studiach przez dwa lata, do końca czerwca 1871 roku, pracował jako prywatny nauczyciel dwóch najstarszych synów Jana Orsettiego i jego żony Anny (z domu Chościak-Popiel), właścicieli Ujazdu (na ten okres datuje się kilkanaście utworów). W czasie tego pobytu zetknął się z Pawłem Popielem i jego rodziną. Dzięki tej znajomości, a szczególnie kontaktom z Jadwigą Chościak-Popiel, późniejszą żoną hrabiego Feliksa Rostworowskiego, stał się miłośnikiem sztuki włoskiej, a także jej koneserem i znawcą, o czym świadczy fakt, że już w 1874 roku wydał opatrzony własnym wstępem, dziś uchodzący za rzadkość antykwaryczną, album w serii Muzeum sztuki europejskiej (Seria druga) ${ }^{9}$. Po

8 Por. M. Sosnowski, K. Jaworski, Wstęp, w: A.R. Świętochowski, dz. cyt., s. VIII-IX.

9 Zob. Muzeum sztuki europejskiej. (Seria druga): Galerie włoskie - zbiór celniejszych obrazów w kopiach na stali, z dodaniem rysu dziejów sztuki włoskiej przez A.S., t. 1: Muzeum Watykańskie i Kapitolińskie w Rzymie, Narodowe w Neapolu, Galerie Pitti i Uffizi we Florencji, galerie pałaców Borghese, Rospigliosi, Sciarra w Rzymie, Pinakoteka Bolońska, freski sykstyńskie itp., Warszawa 1875; t. 2: Muzeum Watykańskie i Kapitolinskie w Rzymie, Narodowe w Neapolu, Galerie Pitti i Uffizi we Florencji, galerie pałaców Borghese, Rospigliosi, Sciarra w Rzymie, Pinakoteka Bolońska, freski sykstyńskie itp., Warszawa 1876; t. 3: Muzeum Watykańskie i Kapitolińskie w Rzymie, Narodowe w Neapolu, Galerie Pitti i Uffizi we Florencji, galerie pałaców prywatnych, Pinakoteka Bolońska, muzea Parmy, Wenecji itp., Warszawa 1878. 
powrocie do Warszawy, 1 sierpnia 1871 roku, rozpoczął pracę w Warszawskim Towarzystwie Ubezpieczeń od Ognia, jednocześnie wykładał geografię powszechną oraz dawnej Polski w prywatnych szkołach męskich i żeńskich. 13 (25) października 1871 roku ożenił się z Heleną Bernhardt, córką znanego warszawskiego lekarza, Adolfa Bernhardta, i miał z nią pięcioro dzieci (czterech synów: Jana, Bolesława, Brunona, Tomasza oraz córkę Zofię). Po trzech latach pracy w Warszawskim Towarzystwie Ubezpieczeń od Ognia stanął na czele Wydziału Ubezpieczeń, od 1885 roku był stałym przedstawicielem Towarzystwa na posiedzeniach Konwencji i przewodniczył zebraniom Komisji Warszawskiej przez cały czas jej istnienia, w styczniu 1900 roku objął obowiązki czasowego zastępcy dyrektora zarządzającego, Konstantego Górskiego, by po dwóch latach zostać pełnoprawnym zarządzającym, a od 1906 roku członkiem Dyrekcji. 19 października 1918 roku na posiedzeniu Rady Zarządzającej z powodu złego stanu zdrowia złożył rezygnację z zajmowanego stanowiska i przeszedł na emeryturę, ale pozostał członkiem Rady. Zmarł 18 grudnia 1928 roku w wieku 84 lat i został pochowany w grobie rodzinnym na warszawskich Powązkach.

Gdy w 1864 roku Andrzej Roch Świętochowski pisał wiersz Sen więźnia (pierwsza zachowana w rękopisie redakcja utworu została zatytułowana Sen), prawdopodobnie nie zdawał sobie sprawy z tego, jak dalece wpisuje się tym wierszem w dziedzictwo żywej tradycji romantycznej - mającej swe postanisławowskie korzenie, wyrastające $\mathrm{z}$ powszechnego $\mathrm{w}$ narodzie polskim poczucia zniewolenia kolejnych pokoleń formacji dziewiętnastowiecznej ${ }^{10}$. Nie wiedział też zapewne, że przepisując w 1918 roku ten sam utwór swojej ukochanej wnuczce Irenie, potwierdzi trwałość narodowej traumy, umacniając tym samym tezę o sile postpamięci zbiorowej ${ }^{11}$. Oddajmy na chwilę głos poecie, przytaczając wiersz w całości, aby - w kontekście tradycji romantycznej - przyjrzeć się jego wymowie ideowej:

10 Por. J. Maciejewski, Wiek XIX jako formacja kulturowa i dziewiętnastowieczność jako antywartość, „Wiek XIX. Rocznik Towarzystwa Literackiego im. Adama Mickiewicza" 2008, R. 1 (43), s. 73-80.

11 Por. K. Kaniowska, Postpamięć indywidualna - postpamięć zbiorowa jako kategorie poznania $w$ antropologii, w: Pamięć i polityka historyczna, red. S.N. Nowinowski, J. Pomorski, R. Stobiecki, Łódź 2008, s. 68. Por. Antologia studiów nad traumą, pod red. T. Łysaka; przekład T. Bilczewski, K. Bojarska, J. Burzyński, A. Kowalcze-Pawlik, A. Rejniak-Majewska, Kraków 2015. 
SEN WIĘŹNIA

Widziałem okrutnika siedzącego dumnie;

Hardy wzrok, strach budzący, dziko zwrócił ku mnie.

Jam stał milczący, patrząc spokojnie i śmiało, Jam czuł i słyszał wszystko, co się wkoło działo.

Skinął... wszyscy, znający taki rozkaz głuchy,

Porwali z trzech związanych jednego w łańcuchy.

„Mów tu przed wielkim tronem, gdzie ci winowajcy,

Gdzie owi buntowników wspólnicy i zdrajcy,

Którzy śmieli zbójecko godzić w piersi cara,

Mów synu wrażych Lachów, bo inaczej kara

Straszliwa dla was wszystkich czeka przyrządzona”.

Więzień powstał, chce mówić, słowo w ustach kona.

Milczy więc, milczy długo, car się niecierpliwi,

A biada temu, kto się carowi sprzeciwi.

Car wielki i tron carów potężny zasiada,

Więc biada! gdy pytany Lach nie odpowiada,

Pyta car groźny jeszcze, ale lasze plemię

Milczy i wzrok ponury spuściło na ziemię,

Jakby chciało jej łono wskroś przewiercić okiem

I ukryć tajemnicę w jej sercu głębokiem,

Ukryć przed carską zgrają. Car pyta raz drugi -

Lecz więzień, jak marmuru głaz, milczy... drżą sługi...

Wreszcie car zawrzał gniewem, spienił się od złości

I krzyknął: „trzysta pałek bić mu bez litości!”.

I wnet go straszni carscy porwali siepacze,

Zawiedli do więzienia to ciało tułacze,

By z laszych piersi wyrwać nienawiść tyrana

I knutem wpoić miłość hord moskiewskich pana,

I toczyć krew szlachecką i zadawać męki.

Jam stał... jam słyszał tylko nieszczęsnego jęki

Straszne, rozdzierające przez bramę otwartą,

Jak człowieka, któremu z ciała pasy darto.

I myślałem, że krzyk ten wielki, bolejący,

To głos nas wszystkich, pomsty nieba wzywający.

I myślałem, że wielki Bóg, jeśli jest w niebie,

To ten krzyk skargi słyszy i da nam w potrzebie

Pomoc mściciela wieków, mściciela-anioła,

Co nam skruszy kajdany i cierń wyrwie z czoła.

Wtem wicher wielki zawył, grom wstrząsnął budową

I starzec siwy zawisł ponad carską głową.

„Ktoś ty jest?”- car zdumiony i przelękły rzecze.

- „Jam jest wysłannik Boga, mściciel-duch, człowiecze!

Drżyj nędzniku! Jam cień ów drogich moich braci,

Których, za wolność, twoi umęczyli kaci.

Krew ich woła spod ziemi o zemstę do Boga

I zwrócenie ojczyzny rozdartej przez wroga. 


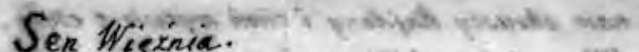

Widria tem okrutnita jiedragege dumnie:

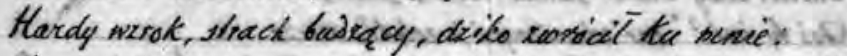

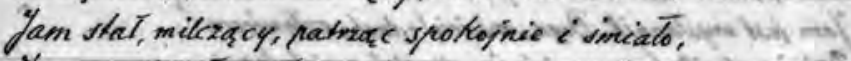

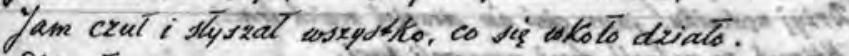

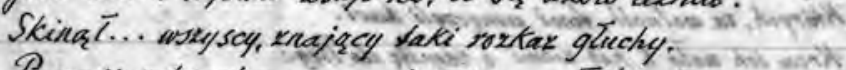

Pormali $z$ treced zoi zony orswali z triech swigzony ed jedrego paricuehy.

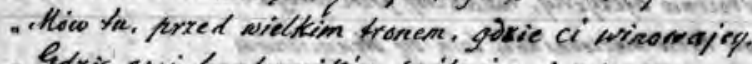

- Edrie owi buntownitiós spolncicy i rdrajaye

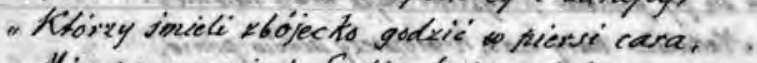

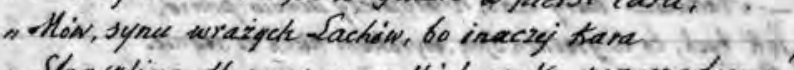

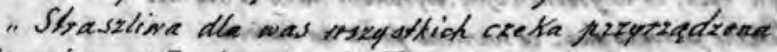

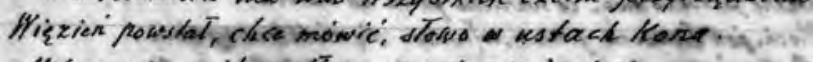

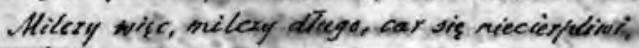

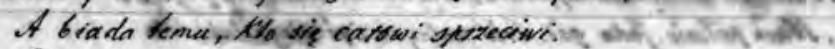

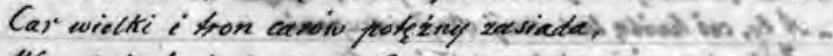

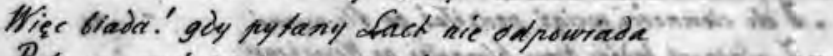
Pyta car grovinig jesscze, ale lasze plensic

Hilcry i wrok ponury thascilo ha tientes.

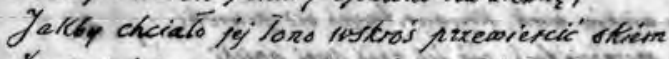

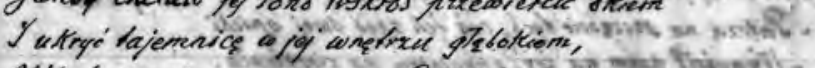

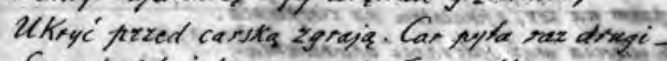
Leer wiezies jat momura plax milom

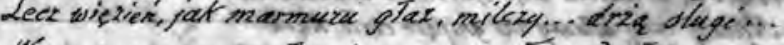

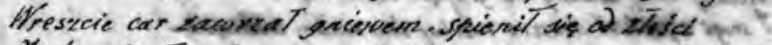

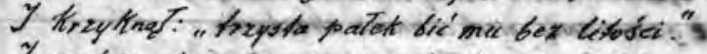

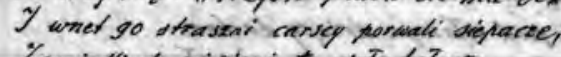

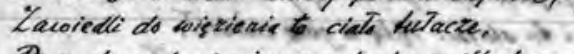

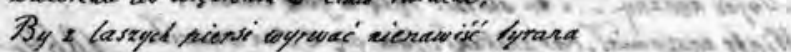
7 Hnuten wpié mitosi hord mostieustich pare.

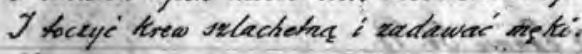

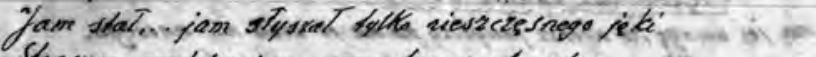

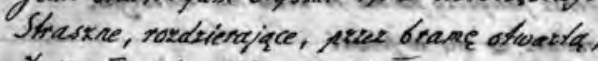

Yat catowienta, Nobreme e ciala pasy derto.

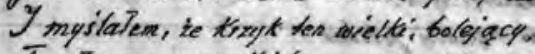

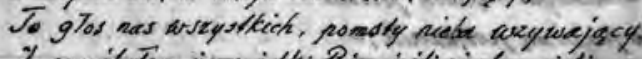

I nysitatem, ie widtic Bog jests jest a cietis

To ten brys sntargi systy ida nax a potrabli.

Qomoc miciciela arietón, miciciela-aniola,

Fragment rękopisu Snu więźnia Andrzeja Rocha Świętochowskiego.

Archiwum rodzinne Ewy Beaty i Mirosława Sosnowskich

Długo krew męczenników lała się strumieniem,

Jam się jej pomścić przyszedł mych braci imieniem.

- Nadchodzi kary czas krwiożerczy ludów panie!

Jęk tych, co w grobach śpią, wyrokiem niech ci stanie. 
Potężne państwo twe, co rozniosło fałsz na świecie, Niech jak Samsona gmach własnym się cielskiem zgniecie.

Podłych służaków rój, narzędzie twoich zbrodni, Niech pełznie jako gad. Śród wolnych żyć niegodni.

A ty, coś hańbą lud swój okrył i trupami

I do ciemności wciąż pędziłeś go tłumami

I własnych ludów krew bluzgałeś po Wszechrusi,

Niechaj cię ciężar krwi własnych twych ludów dusi.

Niechaj po wieków wiek krwawe twych ócz powieki

Patrzą na szczęście tych, coś ich spod swej opieki

Wypuścił psom na żer, oprawcom na cierpienia.

Niech cię sumienia wąż splotami opierścienia.

Niechaj twój własny ząb gnijące ciało kąsa

I srogi z piekieł dreszcz niechaj tym ciałem wstrząsa -

I serce gadzin zwój niech ci owinie strachem -

I aż na wieki żyj, pod własnym drżący dachem.

Pójdź nędzny!” - i tu starzec rękę w górę zwrócił,

Wiatr zaszumiał, car zniknął, jam się z snu ocucił. ${ }^{12}$

Wiersz Andrzeja Świętochowskiego wykorzystuje zasygnalizowaną tytułem konwencję snu, a podmiot liryczny rekonstruuje oniryczną sekwencję wydarzeń, przedstawiającą z perspektywy świadka carski sąd nad więźniem, Polakiem, prawdopodobnie spiskowcem. Oniryczny charakter wizji potwierdzony zostaje w ostatnim wersie utworu: „Wiatr zaszumiał, car zniknął, JAM SIĘ z SNU OCUCıє [wyróżn. - M.S.]”. Dopiero na końcu wiersza czytelnik orientuje się, że uczestnictwo podmiotu, który - w związku z wyraźną epickością Snu więźnia - można także określać mianem narratora wizji, w akcji utworu ma miejsce nie na jawie, a we śnie. Początek wiersza nie określa bowiem dystansu podmiotu-narratora wobec opisywanych zdarzeń, odbiorca ma wrażenie, że pozostaje on jednym z bohaterów, jak wiemy z tytułu, więźniem, aktywnym obserwatorem ciągu zdarzeń. To z nim właśnie car-kat nawiązuje kontakt wzrokowy: „Hardy wzrok, strach budzący, dziko zwrócił ku mnie". Tę aktywność obserwacyjną podmiotu-narratora wyrażają wersy, w których są użyte formy czasownikowe: „Widziałem okrutnika siedzącego dumnie”; „Jam stał, milczący, patrząc spokojnie i śmiało”; „Jam czuł i słyszał wszystko, co się wkoło działo”; „Jam stał..., jam słyszał tylko nieszczęsnego jęki”; „I myślałem, że krzyk ten wielki, bolejący”; „I myślałem, że wielki Bóg, jeśli jest w niebie”; „Wiatr zaszumiał, car zniknął, jam się z snu ocucił”. Podmiot onirycznej wizji żywi nadzieję, że oglądana kaźń współwięźnia, której nie może zapobiec, nie pozostanie bez Bożej pomsty. Pomsta przychodzi 
nadspodziewanie szybko: „mściciel-anioł”/ „mściciel-duch”, który objawia się jako Boży wysłannik i sędzia, oskarża cara i zaborcę oraz niczym Archanioł Michał wymierza sprawiedliwość, strącając cara (który może być tu rozumiany jako personifikacja demona-ciemiężyciela, anioła ciemności) w otchłań piekielną.

W warstwie ideowej utwór - przez aktualizację symboliki biblijnej i wizję pomsty niebieskiej, a także usytuowane tu w centrum zagadnienie sądu i kary, jaką sprawiedliwy Bóg wymierzy ciemiężycielom Polski, w tym szczególnie znienawidzonemu carowi opisanemu w utworze za pomocą epitetów eksponujących takie cechy, jak zwierzęcość, dzikość i tyraństwo ${ }^{13}$ - zbliża się do kanonu polskich utworów martyrologicznych na czele z Dziadami. Częścią III Adama Mickiewicza ${ }^{14}$ (i wplecionym w ich dramatyczną strukturę opowiadaniem Sobolewskiego) czy Anhellim Juliusza Słowackiego. Wers - błaganie o wybawiciela: „Co nam skruszy kajdany i cierń wyrwie z czoła” - powiela natomiast mesjanistyczno-martyrologiczne wyobrażenie Polski jako Chrystusa narodów ${ }^{15}$. Wątek spisku na życie cara, w którym miał uczestniczyć sądzony w utworze więzień, odsyła z kolei do motywu spisku koronacyjnego w Kordianie Słowackiego (scena IV aktu III). Dziedziczone zniewolenie i postawa ofiarniczego współcierpienia bohaterów utworu - dominanty onirycznej wizji Świętochowskiego - to oczywiście cechy dystynktywne opisywanej przez Janusza Maciejewskiego formacji dziewiętnastowiecznej, która, powtórzmy - odnajdując swój rodowód w czasach postanisławowskich - i „bólem śmiertelnym ścieśnione ma serce” ${ }^{16}$. „To GŁOS NAS WsZYsTKICH, pomsty nieba wzywający [wyróżn. - M.S.]" - pisze Świętochowski.

Jest to zatem głos nie jednej osoby, a całej generacji. Tę powszechność

Podobny obraz wszechmogącego Boga - za dobro wynagradzającego, a za zło karzącego - kreuje Świętochowski w wierszu Fiat iustitia (Marzenie). Zob. Upominek. Książka zbiorowa na cześć Elizy Orzeszkowej (1866-1891), Warszawa 1893, s. 83-85 (w druku pominięto trzy strofy wiersza).

14 Świadectwem Mickiewiczowskich inspiracji w poezji Świętochowskiego jest także m.in. wiersz Modlitwa grzesznego, który, jak odnotowuje autor, powstał w 1867 roku w Warszawie „po roztrząśnięciu jednej «myśli» Adama”.

15 Wątek chrystologiczny i millenarystyczny Świętochowski sfunkcjonalizuje także w 1868 roku w obszernym wierszu - czy może wręcz poemacie wizyjnym - Rocznica 29 listopada 1830 roku, a także w pochodzącym z 23 marca 1867 roku wierszu Zmartwychwstanie Pańskie: „I skarżę się, żeś skonał za grzechy ludzkości / I śmiercią swoją świat ten odkupił nieprawy, / A my dla wszystkich ludów na krzyż wbili kości / A my dla wszystkich ludów sztandar niesiem krwawy!".

16 Por. P. Żbikowski, „...bólem śmiertelnym ściśnione mam serce...”. Rozpacz oświeconych. U źródeł przełomu w poezji polskiej lat 1793-1805, Wrocław 1998. 
podkreślił poeta w wierszu - polemice z opinią osoby, której przesłał Sen więźnia. Nie znamy recenzji tego liryku, sformułowanej przez czytelniczkę kryjącą się pod inicjałami St.B., zachował się natomiast utwór Świętochowskiego z roku 1864, zatytułowany Odpowiedź Pannie Stefanii B. na jej uwage, $\dot{z}$ e wiersz poprzedni nie ma $w$ sobie nic nowego. O pokoleniowej spuściźnie „dawnych mar” i cierpień, jakie dręczą Polaków, zaświadcza w wierszu - odpowiedzi fragment, w którym autor niejako tłumaczy się korespondentce z epigońskiego użycia i sfunkcjonalizowania w liryku tradycyjnych romantycznych kodów ${ }^{17}$; pyta retorycznie:

Więc to wielkie przewinienie,

Żem ukochał DAWNE MARY,

Żem je do mej pieśni wziął -

I żem CZUJĄC BÓL, CIERPIENIE

Starą klątwą wrogów klął? ${ }^{18}$

Wygłosem tej postawy staje się rozpaczliwy w tonie, ale niepozbawiony nadziei fragment Odpowiedzi Pannie Stefanii B. [...]:

Myśmy Polskę w łzach ujrzeli,

Gdy zawisła nad nią kara:

Od dzieciństwaśmy wiedzieli,

Że ból stary i łza stara -

I przez całe nasze życie

Żadna gwiazda na błękicie

Żywszym światłem nam nie błysła

I weselem nie oblała,

Tylko noc się rozszalała

I nad nami krwią zawisła.

Póty nie znam innej nuty,

Prócz tej, co mi w SERCU TKWI:

A gdy komu ta żałoba

W mych się pieśniach nie podoba -

Lub jeśli się nuta dawna

Wyda znana, niezabawna -

Ha! cóż robić? Przykra rzecz,

Iść nie mogę myślom wstecz,

Aby za wiersz modny, śmiały

17 O romantyzmie i jego potężnym wpływie na lirykę okresu postyczniowego, zwłaszcza u „przedburzowców” - zob. J. Maciejewski, Przedburzowcy. Z problematyki przełomu między romantyzmem a pozytywizmem, Kraków 1971, s. 123-133.

18 Ten cytat $\mathrm{z}$ wiersza Świętochowskiego i kolejne przytoczenia pochodzą - jeśli nie zaznaczono inaczej - z rękopisów znajdujących się w zbiorach rodzinnych Ewy Beaty i Mirosława Sosnowskich. 
Zyskać oklask lub pochwały.

Bo dopóki kask zakuty

I dopóki serce w krwi,

Póty nie znam innej nuty,

Prócz tej co mi w duszy tkwi.

Nuty żalu i męczeństwa,

Albo cichych łez i jęków

Lub rozpaczy i przekleństwa

I więziennych kajdan brzęków.

Dzisiaj boleść i cierpienie

To nasz pokarm, napój nasz,

A łzy, co lśnią przez rzęs cienie,

To NASZ UŚMIECH - ZWYKŁA TWARZ.

Jeśli pokarm Bóg odmieni,

Jeśli napój poda czysty,

I uśmiechem twarz spromieni,

I dzień błyśnie przezroczysty -

Wtedy niech ci wzrok rozpłonie

Niech nie patrzy na świat łzawo,

Tylko śmiej się, klaskaj w dłonie,

Wołaj nowin, bo masz prawo. ${ }^{19}$

Oba przytoczone wiersze Andrzeja Świętochowskiego świadczą o bardzo dobrej znajomości - dającej o sobie znać zresztą wśród całego pokolenia debiutującego w latach sześćdziesiątych - romantycznej poezji polskiej, która stawała się wzorcem i pierwszym punktem odniesienia dla poetyckich wprawek, nadto pokazuje charakterystyczny dla przedstawicieli całej formacji sposób komunikacji poetyckiej, którego mechanizmy czekają jeszcze na gruntowne zbadanie, a który ma swoją odsłonę także w dialogu prowadzonym na łamach czasopism. Oczywiście, ostatecznie nie dziwi też stwierdzenie interlokutorki, do której Świętochowski zaadresował wiersz - odpowiedź - mianowicie, że nie znajduje żadnej nowej jakości estetycznej i ideowej w Śnie więźnia.

Czy rzeczywiście w przytoczonym utworze mogło być coś nowego dla przedstawicielki pokolenia, które literaturę romantyczną znało na pamięć? I chociaż nie sposób odmówić Świętochowskiemu talentu wierszopisarskiego, to jednak podobne wrażenie epigońskości odniesiemy, próbując odczytywać utwory pochodzące z wczesnej fazy twórczości (analiza ocalałego materiału rękopiśmiennego ${ }^{20}$ wskazuje, że autor najwięcej utworów napisał w latach 1863-1870). To najczęściej teksty o charakterze autorefleksyjnym.

20 Ocalały materiał literacki nie jest pełny, jak wynika z zapisków autora. 
Czytając je, wyraźnie dostrzegamy, że preorganicznikowski pancerz okrywa ducha dręczonego postyczniową melancholią (lub też występuje pewnego rodzaju napięcie między tymi dwoma porywami duszy - rozpaczą i nadzieją), chciałoby się za Marianem Płacheckim powiedzieć - jeszcze jednego „dekadenta południa wieku” ${ }^{21}$, który nieustannie przepracowuje narodową traumę i wyłącznie w odniesieniu do stygmatu narodowej niewoli i związanych z nią cierpień potrafi definiować własną podmiotowość i powinności. Zacytujmy wiersz o incipicie ${ }^{\star * *}$ I po cóż, Panie, dałeś mi życie:

I po cóż, Panie, dałeś mi życie,

Gdy ciągle jęcząc, żyć muszę?

Gdy słyszę braci męki i bicie

I srogie Polski katusze?

I po cóż, Panie, dałeś mi serce,

Gdy ono kochać nie może?

Gdy z niego wszystko wzięli morderce?

Tam teraz z lodu jest łoże!

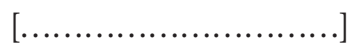

Sercem nie kocham, życiem nie żyję,

Duszą świętości nie czuję!

Życie zgnilizną! W sercu złość kryję!

A w duszy szałem wiruje!

Rozpacz, zwątpienie, odrętwienie, niedola, uciśnienie, tęsknota za wolnością - to, jak wynika ze wstępnych rozpoznań, tematyczne kręgi dominujące w liryce refleksyjnej i refleksyjno-patriotycznej Andrzeja Świętochowskiego. Minorowa tonacja sprawia, że utwory te wpisują się w cały pejzaż kulturowych świadectw narodowego dramatu szukającego artykulacji $\mathrm{w}$ różnych sztukach oraz na ich pograniczu - w metaforyce i symbolice eksponującej obrazy rozbicia i rozkładu (w wymiarze stosunków społecznych - anomii), które, jak zgodnie oceniają badacze formacji dziewiętnastowiecznej, „charakteryzowały społeczeństwo polskie i sytuację psychiczną jego przedstawicieli w literaturze pięknej całego wieku XIX” ${ }^{22}$. W duchu martyrologicznym utrzymany jest szereg innych jeszcze utworów poetyckich Świętochowskiego, między innymi Zmartwychwstanie Pańskie (1867), Ojciec i syn

21 Por. M. Płachecki, Nerwy. Aporie wyboru, w: tegoż, Wojny domowe. Szkice $z$ antropologii słowa publicznego w dobie zaborów (180o-1880), Warszawa 2009, s. 287-309.

22 Por. B. Bobrowska, Dezintegracja osobowości a dezintegracja społeczna - świadectwa dziewiętnastowieczne, w: Pozytywizm i negatywizm. „My i wy” po stu latach, red. B. Mazan, współpr. S. Tynecka-Makowska, Łódź 2005, s. 454. 
na Sybirze (1870), Rocznica 29 listopada 1830 roku (1868), Ostatni ton (bez daty).

Przeprowadzona tutaj wstępnie charakterystyka spuścizny poetyckiej Andrzeja Rocha Świętochowskiego skłania do postawienia pytania, czy gdyby autor poszedł drogą literacką i próbował wspiąć się na poetycki Parnas, to i jego nastrojoną na postromantyczne tony lirę „zabiłaby” - by użyć sformułowania Jana Tomkowskiego ${ }^{23}$ - i zmarginalizowała antypoetycka krytyka epoki. Z jej charakteru zresztą Świętochowski w pełni zdawał sobie sprawę, pisząc w swoich wspomnieniach: „Poezję spychano [wtedy - M.S.] z piedestału, bo szybując w obłokach, spowodowała «wybujały patriotyzm»" ${ }^{24}$. Oczywiście to tylko luźne rozważania. Wiemy przecież, że poezja postyczniowa rozwijała się mimo nieprzychylnych jej opinii ${ }^{25}$.

Zachowana spuścizna literacka Świętochowskiego, z której przytoczono tutaj kilka fragmentów, stanowi ponad pięćdziesiąt czekających na edycję utworów o charakterze lirycznym, głównie o tematyce autorefleksyjnej, patriotycznej, miłosnej, okolicznościowej oraz oryginalny, nieukończony dramat Stanisław Lach, a także rozpoczęte przekłady dramatów Friedricha Schillera Don Karlos. Infant hiszpański oraz Spisek Fieska w Genui. Zawiera ponadto dłuższe formy, są to: wierszowana epika Alina (fragment), poematy Savonarola, Intermezzo i Ostatni ton oraz poemat dramatyczny Miłość. Znikomą część wymienionych utworów ogłosił Świętochowski drukiem na łamach czasopism i w książkach zbiorowych epoki. Publikował w czasopismach (np. „Tygodniku Ilustrowanym” ${ }^{26}$ ), w wydawnictwie zbiorowym Upominek. Książka zbiorowa na cześć Elizy Orzeszkowej. Taki stan rzeczy świadczyć może z jednej strony o autokrytycyzmie autora i wysokich wymaganiach, jakie stawiał swoim literackim próbom, albo o ostrzu krytyki redaktorów pism, którzy proponowanych do publikacji utworów drukować - ze względu na ich postromantyczny charakter - nie chcieli.

23 Por. J. Tomkowski, Samobójcy i marzyciele. O zabijaniu poetów, Kielce 2002.

24 A.R. Świętochowski, dz. cyt., s. 129.

25 O kierunkach rozwoju poezji po 1863 roku - zob. T. Budrewicz, Rymowane spory. Asnyk, Kraków 2015; T. Budrewicz, Wierszobranie (druga połowa XIX wieku), Kraków 2016; T. Budrewicz, Między rymem a Muzą, Kraków 2017.

26 Zob. Andrzej R.S. [A.R. Świętochowski], Na ruinie zamku Krzyżtopór, „Tygodnik Ilustrowany" 1871 , nr 209, s. 338. W dokumentach biograficznych z archiwum rodzinnego Sosnowskich znajduje się informacja, że Andrzej Roch Świętochowski publikował też w „Kurierze Niedzielnym” i w „Gazecie Polskiej”. Zob. np. A. Świętochowski, W Bazylice Św. Piotra w Rzymie, „Kurier Niedzielny” 1897, nr 3, s. 26 [red.]. 
Poetyckie i translatorskie próby towarzyszyły jednak Andrzejowi Świętochowskiemu przez całe jego pracowite życie, znalazły swoje miejsce - co wcale nie wyróżniało go na tle innych absolwentów Szkoły Głównej, tych „gońców z pochodnią" ${ }^{27}$ - na marginesie pracy zawodowej, której poświęcił się odpowiedzialnie, całym sercem. „Wiek męski nie był - pisał nie bez pewnej goryczy w swoich wspomnieniach - wiekiem «klęski», jeśli mowa o materialnym powodzeniu życiowym, ale był nim moralnie, bo warunki polityczne zepchnęły mnie z drogi naukowej i literackiej na obcą mi drogę handlowo-przemysłową" ${ }^{28}$. Droga życiowa, którą obrał Świętochowski, niestety ochłodziła jego ambicje i uzdolnienia literackie i nadała im nowy kierunek. Bogate życie rodzinne i zawodowe aż prosiło się o wykorzystanie rymotwórczych uzdolnień w sposób nieco bardziej instrumentalny - od teraz czyniły one zadość nie tyle (nie zawsze) natchnieniu, lecz doraźnym potrzebom chwili, wzbogacały prywatne i służbowe uroczystości, opiewały jubileusze, imieniny, pełniły funkcję toastów, rymowanych laudacji czy poetyckich listów.

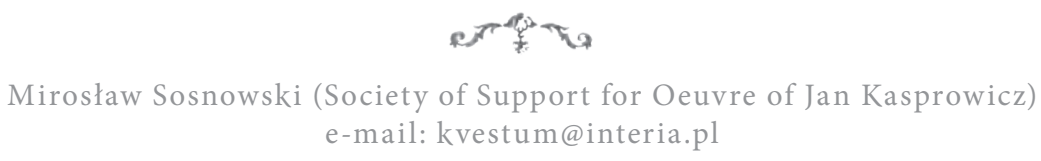

On the Outskirts of the Literature:

The Portrait of Andrzej Roch Świętochowski the Poet of Inherited Trauma

\section{A B S T R A C T}

The article is a presentation of the silhouette of Andrzej Roch Świętochowski - geographer, art historian, tutor and private school teacher, long-time director of the Warsaw Fire Insurance Society, author of unpublished translations of Friedrich Schiller's plays and original poetry, epic poetry; memoirs, and scientific dissertations. In the article the author analyzes and interprets one of the early poems by Świętochowski - The Prisoner's dream in the context of Romantic tradition.

\section{KEYWORDS}

Andrzej Roch Świętochowski, January Uprising, poetry of the second half of the 19th century, trauma

27 J. Kotarbiński, Sienkiewicz i pokolenie Szkoły Głównej, w: Szkoła Główna - Sienkiewiczowi, Warszawa 1917, s. 13.

28 A.R. Świętochowski, Moja spowiedź skrócona, w: tegoż, dz. cyt., s. 201. 